\title{
Lessons from Viral Superinfections for HIV-1 Vaccine Design
}

\section{Stephanie Jost*}

Ragon Institute of MGH, MIT and Harvard, USA

\begin{abstract}
Superinfection refers to a second viral infection in the context of a pre-existing adaptive immune response to prior infection with a viral strain that has not been cleared, the two viruses being genetically distinct yet belonging to the same genus. As such, this phenomenon provides unique settings to gain insights into the immune correlates of protection against HIV-1. The focus of this review is to discuss the current knowledge about immune responses to HIV-1 and to other viruses that are associated with partial or complete immunity to superinfection, or lack thereof, and how that could be applied to future HIV-1 vaccine strategies.
\end{abstract}

Keywords: HIV-1; Superinfection; Vaccine; Co-infection; Viral infection; Recombination

\section{Introduction}

The human immunodeficiency virus type 1 (HIV-1) affects 34 million adults and children worldwide, and the ongoing spread of the epidemic resulted in about 2.5 million new infections and 1.7 million deaths in 2011 alone [1]. Novel approaches to prevent transmission of HIV-1 are urgently needed to stop the epidemic. To date, prophylactic vaccines have proven to be the most efficient means to counteract the spread of human pathogens and increase global human health. However, the design of preventive vaccines against some infectious agents, including HIV-1, remains a tremendous challenge. Thus far, different HIV-1 vaccine candidates have been tested in efficacy trials and two major attempts, first to induce HIV-1 neutralizing antibodies (VAX004), then effective HIV-1-specific T cell responses (Step study) were unsuccessful (reviewed in [2]). These approaches were followed by two vaccine trials aimed at promoting both, humoral and cellular responses, one of which was recently discontinued based on interim results showing no evidence of protection (HVTN 505) [3], while the other provided about $30 \%$ protection, yet only with borderline significance (RV144) [4].

HIV-1 superinfection has gained increasing attention as it provides a unique opportunity, aside from vaccine trials, to determine the immune factors promoting protection from HIV-1 infection. The increasing amount of documented HIV-1 superinfections in the literature suggests that the adaptive immune response mounted upon a primary infection with a single HIV-1 strain might not be effective enough at protecting against a distinct HIV-1 strain, even a closely related one. Therefore, concerted efforts have been directed at characterizing the immune response prior to and after HIV-1 superinfection, or that in exposed singly HIV-1-infected individuals, in order to identify associations between the quality and the quantity of the immune response and the occurrence of HIV-1 superinfection. Herein, I review the current knowledge on the prevalence and the clinical consequences of HIV1 superinfection, and discuss the immune and viral mechanisms accounting for protection from, or acquisition of, HIV-1 and other viral superinfections. A complete understanding of why exposure to HIV-1 or to other viruses does not confer protective immunity to a second infection will help identify the correlates of immune protection in HIV-1 infection, and contribute to improving future HIV-1 vaccine strategies.

\section{HIV-1 Rapid Evolution and Diversity: A Challenge for Vaccine Design}

The extremely rapid evolution of the virus probably largely contributed to the failure or limited success of HIV-1 vaccines evaluated to date [5]. HIV-1's extensive genetic diversity was first brought to light around 1983, when full-length sequences of the virus became available, and has since then expanded [6]. Distinct mechanisms account for the emergence of remarkably divergent variants. These include the infidelity of the viral reverse transcriptase, the high replication rate and fast turnover of virions, host selective immune pressure, large insertions, deletions, mutations introduced by intrinsic restriction factors such as cytidine deaminases of the APOBEC family and, last but not least, recombination events in dually-infected individuals (reviewed in $[7,8])$. Recombinant forms arising from two parental strains of distinct subtypes can be easily detected, while intra-subtype recombination fails to be reliably identified by most current methods. At a time when HIV1 dual infections had not been adequately documented, the existence of recombinant forms provided the strongest support for their occurrence, which represents an important mechanism to generate new divergent HIV-1 strains. For instance, at the time HIV-1 superinfection was first reported in humans in 2002 [9-11], 14 circulating recombinant forms (CRFs) had been described. Today, the Los Alamos database reports 58 HIV-1 CRFs and 1 HIV-2 CRF, and as more HIV-1 variants inevitably intermix in different parts of the world, the likelihood of generating new recombinant viruses increases [6]. An expanding number of reports of new HIV-1 variants is also to be expected, as improvements in surveillance methodology will allow for a more comprehensive control of the ongoing expansion of HIV-1 diversity.

Therefore, HIV-1 dual infections are driving evolution of the virus and as such directly affect the development of an effective HIV-1 vaccine. On the other hand, studying HIV-1-specific immune responses in individuals who were sequentially infected is highly informative with respect to a better understanding of the correlates of protection from HIV-1 infection.

*Corresponding authors: Stephanie Jost, Ragon Institute of MGH, MIT and Harvard 400 Technology square, Cambridge MA 02139, USA, E-mail: sjost@partners.org

Received May 20, 2013; Accepted June 20, 2013; Published June 26, 2013

Citation: Jost S (2013) Lessons from Viral Superinfections for HIV-1 Vaccine Design. J AIDS Clinic Res S3: 005. doi:10.4172/2155-6113.S3-005

Copyright: ( $) 2013$ Jost S. This is an open-access article distributed under the terms of the Creative Commons Attribution License, which permits unrestricted use, distribution, and reproduction in any medium, provided the original author and source are credited. 


\section{HIV-1 Superinfection}

HIV-1 superinfection is not to be confounded with HIV-1 coinfection, which refers to infection with two genetically distinct HIV-1 strains simultaneously, or with exposure to the second virus occurring within the small window of time (about a month) prior to seroconversion (reviewed in [12]). In contrast, superinfection is used to describe a secondary infection with a heterologous or homologous HIV-1 strain, which takes place any time once an adaptive immune response to the initial HIV-1 virus is established. In accordance with this nomenclature, both phenomenons can be termed 'dual infections'. Before 2002, it was generally believed that HIV-1 superinfection could not occur in humans. The major observations to uphold that idea came from in vitro studies, which demonstrated the existence of diverse mechanisms at play in HIV-1-infected cells to block subsequent entry of viruses [13-15]. For instance, HIV-1 nef mediates CD4 down regulation, preventing access to the main receptor used by HIV-1. However, uninfected CD4+ T cells in HIV-1-positive individuals could provide a target for subsequent HIV-1 virus infection. Moreover, early containment of HIV-1 replication, observed in most acutely infected individuals when HIV-1 specific CD8+ T cells and antibodies first appear, was thought to reflect a partial immune protection that would prevent a different HIV-1 strain from establishing a superinfection. However, many reports had described individuals infected with two distinct HIV-1 strains, and although it had not been clear, whether these were co- or superinfections, both scenarios remained conceivable (reviewed in [12]).

Before any conclusive case had been reported in humans, HIV-1 superinfection was induced experimentally in chimpanzees, and the second infection produced a slower immune deterioration and more efficient control of viremia compared to the initial infection [16]. This report was followed by additional studies documenting HIV-1 and SIV superinfections in monkeys [16-22]. However, the extent to which these results can be applied to human HIV-1 superinfection remains to be thoroughly determined. Indeed, HIV-1 or SIV-infected monkeys do not develop AIDS and get experimentally infected in very controlled settings, including choice of the infectious dose, viral strain, route and timing of infection, which don't recapitulate natural infection in humans.

The first documented cases of superinfection in humans were published only 10 years ago [9-11]. Since then, multiple reported cases have described interclade $[10,11,23-29]$ as well as intraclade [9,30-35] superinfections, but also triple superinfections [28,32,36], or superinfections involving substantially divergent strains belonging to the different HIV-1 and HIV-2 groups [37,38].

\section{Role of $T$ cell responses in $H I V-1$ superinfection}

The first convincing report of HIV-1 superinfection described two events in injection drug users (IDUs), with the second HIV-1 strain belonging to a different subtype in both situations [11]. Co- rather than superinfection could not be entirely excluded, yet humoral and cellular immune responses were exclusively directed against one HIV-1 strain prior to potential exposure to the second virus, strongly suggesting superinfection, with cross-reactive humoral and cellular responses developing after presumed infection with the second strain. A second well-documented case described a superinfection with an HIV-1 strain of subtype $\mathrm{B}$, which rapidly overgrew the established HIV-1 subtype AE in a male following sexual exposure with multiple same-sex partners [10]. Interestingly, the individual was treated with antiretroviral therapy for at least 18 months following primary infection before receiving the
Alvac vCP1452 vaccine and stopping treatment as part of the protocol. Superinfection occurred 6 months after immunization while off therapy. Initially, AE-subtype-specific CD8+ T cell responses were directed against a single p17 Gag epitope, and disappeared upon superinfection with the clade B HIV-1, against which no virus-specific CD8+ T cell responses could be detected. In this subject, the primal narrow range of CD8+ T cell responses might partly account for the rapid progression of the disease triggered by the superinfecting virus. Neither HIV-1specific antibodies nor CD4+ $\mathrm{T}$ cell responses were investigated in this case, but might have contributed to the lack of control. At the same time, a case of HIV-1 superinfection involving two subtype B strains was also reported [9]. The individual enrolled in a structured treatment interruption trial after the initial infection, and developed a strong and broad HIV-1-specific CD8+ T cell response over time. Strikingly, about half of this response appeared to be cross-reactive and persisted upon superinfection, with the second virus triggering CD8+ $\mathrm{T}$ cell responses directed against three additional epitopes. While the neutralizing antibody response was found to be low, a cellular response of this magnitude and breath did not translate into protection against the second HIV-1 strain even though its sequence only differed by $12 \%$. Thus, these and additional well-documented cases demonstrated that superinfection can occur in the context of limited HIV-1-specific cytotoxic $\mathrm{T}$ cell responses mostly directed against a single epitope $[10,35]$, yet it is not prevented by the presence of broad responses to multiple epitopes $[9,11,34,39]$.

A recent study dissecting the breath, magnitude and polyfunctionality of HIV-1-specific T cell responses among high-risk untreated superinfected women and matched singly-infected controls supported previous observations and failed to show an association between cytokine production or cytotoxic activity of HIV-1-specific $\mathrm{CD} 8+$ and $\mathrm{CD} 4+\mathrm{T}$ cells and protection from HIV-1 superinfection [40]. However, in singly antiretroviral-treated HIV-1-infected males engaging in unprotective sex with viremic stable male partners, chronic exposure to HIV-1 was found to be associated with higher HIV-1specific $\mathrm{CD} 4+$ and $\mathrm{CD} 8+\mathrm{T}$ cell IFN $-\gamma$ responses, and correlated with the level of exposure [41]. Thus, further studies are warranted to determine whether repeated HIV-1 exposure of treated HIV-1-infected individuals can promote stronger HIV-1-specific T cell responses that might ultimately be able to control viral replication in the absence of antiretroviral medication.

\section{Role of neutralizing antibodies in $\mathrm{HIV}$-1 superinfection}

While there is no clear evidence of effective cross-protection by HIV-1-specific CD8+ T cells to date, antibodies represent another major component of the immune response that might provide sterilizing immunity against HIV-1 superinfection. High levels of crossreactive neutralizing antibodies (NAbs) have been suggested to prevent superinfection in exposed treatment-naïve HIV-1-infected men having sex with men (MSM) with recent infection [42]. Accordingly, low or undetectable levels of NAbs were present prior to the second heterosexual exposure in three individuals superinfected with HIV-1 subtype C strains, in contrast to singly-infected matched controls who presented HIV-1-specific antibodies with very potent neutralizing features [43]. These results were discordant with the description of untreated female sex workers who became superinfected despite a broad and potent neutralizing antibody response prior to the second infection with an HIV-1 strain that could be inhibited in vitro [44].

More potent neutralizing antibodies have been shown to appear later in the course of HIV-1 infection [45]. Therefore, it is likely that the susceptibility to superinfection is higher during the first year following 
primary infection, when HIV-1-specific humoral immunity is not fully developed, and the discrepancies between the abovementioned studies might be explained by differences in the time elapsed between the initial and the second infection. This hypothesis is supported by initial observations in HIV-2-infected macaques, which can only become productively superinfected by a distinct HIV-2 virus within 8 weeks following primary infection [22], and by a substantial percentage of documented superinfections that occurred within one year of primary HIV-1 infection in humans $[11,30,31,33,34]$.

Interestingly, in untreated HIV-1-infected individuals with heterosexual risk, superinfection with a genetically unrelated HIV1 strain led to the emergence of NAbs that can mediate anti-HIV-1 responses of increased breath and potency compared to the ones present prior to the second infection, suggesting that serial HIV-1 vaccination involving heterologous HIV-1 strains might increase antibody-mediated protection against a broad range of genetically distinct HIV-1 viruses $[46,47]$. However, development of NAbs with increased neutralizing ability in individuals superinfected with discordant HIV-1 strains was not associated with a better control of the HIV-1 strain that initiated the infection [48]. Thus, repeated exposure of HIV-1-infected individuals to the virus, or to a potential therapeutic HIV-1 vaccine, might trigger a skewing of the humoral response, leading to the generation of NAbs that might prevent new HIV-1 strains to establish a superinfection, but are not able to efficiently recognize the already present quasi species.

Beyond their neutralization function, which involves their variable domain, antibodies have the ability to recruit innate effectors cells that express $\mathrm{Fc} \gamma$ receptors via their constant domain, triggering various antiviral mechanisms depending on the type of cells and receptors engaged [49]. Antibodies lacking potent neutralizing properties might provide protection through effective innate immune recruiting activities. So far, one report measured antibody-dependent cell-mediated virus inhibition in singly- and superinfected individuals, yet no correlation between extra-neutralizing functions of antibodies and the risk of HIV1 superinfection could be identified [50].

To conclude, further investigations are required to assess the degree of cross-reactivity that will need to be achieved by the humoral and cellular immune responses to a first exposure to HIV-1, or to a preventive HIV-1 vaccine, in order to provide protection from superinfection, or primary infection, respectively.

\section{What is the incidence of HIV-1 superinfection?}

Overall, increasing amounts of convincing case reports of HIV-1 superinfections seem worrisome for the prospect of developing a crossreactive HIV-1 vaccine. However, despite the flourishing literature on the subject, there is a current lack of technology and available data to clearly determine the incidence of this phenomenon. Cross-sectional studies [51] or longitudinal follow-ups with limited sampling over time [52] might not represent adequate settings to assess superinfection incidence rates. Combined with a lack of adequately sensitive techniques to reliably identify this event, the true prevalence of superinfection is likely to be underestimated and still subject to intense controversy (reviewed in [53]). In some studies focusing on either high-risk or general populations, primary infection and superinfection have been found to occur at a similar frequency (about $5 \%$ per year in high-risk populations) $[23,33,54,55]$. In contrast, superinfection could neither be detected in four distinct cohorts of HIV-1-positive individuals [5659], including injecting drug users (IDUs) [56,59], nor in therapy-naïve MSMs being closely monitored longitudinally around episodes of selfreported unsafe sexual behavior [51]. In two other cohorts of IDUs in
Switzerland and Thailand, $2.5 \%$ of the individuals became superinfected within 2 years and 1 year following seroconversion, respectively [25,29]. These discrepancies can be mostly explained by distinct experimental designs, such as different frequency of sampling and superinfection detection methods, cohort size and risk behavior, but also disparate HIV-1-prevalence and diversity at the site of the study.

The outgrowth of the initial HIV-1 virus by the superinfecting strain can translate into a transient increase in viremia [9,10,28,32-34,54]. Thus, a sudden rise in plasma viral load (at least $0.5 \log 10$ copies $/ \mathrm{ml}$ ), particularly in untreated individuals engaging in high-risk behaviors, might indicate a superinfection event $[29,60]$. However, unexplained increased viremia in subjects that do not take antiretroviral drugs might not represent an entirely reliable predictor as inconsistent rises in viral loads have been suggested to reflect a superinfection event only in $14 \%$ of the cases [61]. Beyond clinical indications, further monitoring is warranted to confirm any suspected superinfection. Pol sequencing alone, which is easily available as part of the routine testing for drug resistance mutations of treated patients, can be used as a second tool to screen for HIV-1 superinfection, which might be associated with consequent changes in the pol sequence and/or treatment susceptibility [60]. Nevertheless, HIV-1 superinfections are more frequently detected when two distinct regions of the viral genome rather than one are sequenced, and samples from different time points analyzed $[52,54,62]$. Finally, a major drawback of population-based sequencing is its lack of sensitivity to detect strains that are underrepresented in the quasi species population, and alternative methods, such as heteroduplex mobility assay and ultra-deep sequencing, might be more appropriate to detect superinfections [63-65].

Therefore, availability of epidemiological data, sensitive screening methods, as well as time and frequency of sampling are all profoundly influencing the ability to detect HIV-1 superinfection events. Notably, we currently can't exclude the existence of HIV-1 superinfections that are controlled by the immune system and therefore remain undetected. Addressing how to accurately measure superinfection incidence rates will be of paramount importance to delineate what constitutes an optimal immune response that will need to be elicited by future HIV-1 vaccines, and whether the level of protection can be predicted by the nature of vaccine-induced immune responses.

\section{Implications of HIV-1 Superinfection on the Outcome of the Disease}

HIV-1 superinfection represents a major public health challenge as this phenomenon might impact treatment efficacy or natural control of the infection. Studies report an overall poor control of the superinfecting virus, which is in most cases associated with a sudden increase in viral load and accelerated disease progression [9-11,26,28$34,42,60,66,67]$. While this could be attributed to a loss of immunemediated control due to a lack of overlap in crucial epitopes between the two HIV-1 strains, it has also been suggested that superinfection preferentially occurs in individuals initially infected with HIV-1 strains displaying a reduced fitness compared to the superinfecting virus [68]. For instance, in the absence of antiretroviral treatment, it has been shown that upon superinfection, wild-type HIV-1 strains can outgrow drug-resistant variants displaying reduced replication capacity $[31,33,34,67]$. Importantly, sudden increases in viral loads might have allowed detection of a significant number of HIV-1 superinfections described thus far, and therefore it is not excluded that less fit and/ or less pathogenic superinfecting strains never outgrow the initial virus and remain unnoticed minority variants with no significant 
impact on disease progression. Overcoming the current technical challenges to reliably detect strains that represent less than $20 \%$ of the total quasi species population will enable investigation into viral and immunological factors contributing to the control of these strains by the immune system.

\section{Impact on the efficacy of antiretroviral treatment}

It is expected that successfully treated HIV-1-positive individuals are less susceptible to productive superinfection than untreated subjects. Accordingly, no superinfection was found in treated highrisk singly HIV-1-infected couples [69]. In cases when treatment does not prevent HIV-1 superinfection, various scenarios, all with a negative impact on the efficacy of antiretroviral treatment, have been illustrated. Superinfections with HIV-1 strains carrying drug resistance mutations have been documented, and can lead to antiretroviral treatment escape and limit therapeutic options for the patient $[32,33,66,70,71]$. In individuals superinfected with two HIV-1 viruses carrying distinct multiple drug resistance mutations, recombination can lead to the generation of a highly drug-resistant HIV-1 strain with severe repercussions on disease outcome [70]. Finally, in cases of superinfection with a fitter, drug-sensitive HIV-1 strain that outgrows the drug-resistant virus, drug resistance mutations might not be detected by conventional testing, and if treatment becomes necessary in these instances, emergence of the occulted drug-resistant HIV-1 strain is likely to lead to treatment failure $[31,33,34,67]$. Finally, it is not implausible that superinfection involving two wild-type viruses could also impact the response to treatment. Indeed, the tendency of particular strains toward higher replication rates might lead to early resistance and treatment failure.

\section{Impact of HIV-1 superinfection on the spontaneous control of HIV-1}

HIV-1 controllers are able to naturally control viral replication, reflected by stable low viremia for at least one year, and have a very small probability of progressing towards AIDS (reviewed in [72]). While the mechanisms underlying viral control are not completely understood, mounting evidence supports a crucial role for specific human leukocyte antigen (HLA) alleles in conferring protection against disease progression. The virulence of the HIV-1 strain that initiates the infection is also decisive for the outcome of the infection, and in that respect, one could speculate that HIV-1 superinfection with a more pathogenic HIV-1 strain (i.e. a strain that escapes cellular immunity) might disrupt the equilibrium between immune control and viral replication in HIV-1 controllers.

Several studies have suggested that spontaneous control of HIV-1 does not imply protection from superinfection [73]. Indeed, a sudden increase in viral load accompanied with symptoms of primary HIV-1 infection revealed an interclade superinfection in two IDUs who were defined as controllers after the initial infection with subtype $B$ and CRF11 HIV-1 strains, respectively. Similarly, superinfection led to febrile illness and disease progression in an HIV-1-positive untreated female sex worker who presented normal CD4 $+\mathrm{T}$ cell counts and low viremia for about 5 years prior to a secondary productive HIV-1 infection [74]. However, the mechanisms underlying the loss of viral control in these unique cases are not clear as the authors did not investigate HIV1-specific humoral and cellular responses, nor did they look at the replication capacity of the initial virus. For instance, rapid generation of recombinant strains following HIV-1 superinfection might significantly enhance the ability of the newly produced virus to evade the immune system in controllers. Indeed, recombination events between the initial and the superinfecting HIV-1 strains within crucial regions targeted by HIV-1-specific CD8+ T cells led to viral escape and disease progression in one individual carrying the protective HLA-B27 allele [35].

In contrast, two studies described HIV-1 superinfections in controllers and long-term non progressors (a distinct group of untreated HIV-1-infected individuals who maintain CD4+ T cell counts $>500 / \mathrm{mm}^{3}$ and display a very slow progression towards AIDS), none of which resulted in disease progression [75,76]. Replication competent HIV-1 strains isolated from the superinfected controllers suggested that some level of cross-reactive protection can be achieved in individuals who spontaneously control the primary HIV-1 infection [76]. Similar to humans, a long-term non-progressor status can be achieved in SIV-infected Rhesus macaques that carry protective major histocompatibility complex (MHC)-class I alleles, such as Mamu- $B^{*} 17$. Superinfection of such animals with SIV strains bearing increasing numbers of mutations allowing escape of Mamu- ${ }^{\star} 17$-restricted-CD8+ $\mathrm{T}$ cells epitopes did not lead to increased viral replication, although these divergent strains had only minor defects in replicative fitness and could infect naïve macaques [77].

Overall, the clinical consequences of HIV-1 superinfection are not yet entirely clear. However, it has been associated with accelerated disease progression and antiretroviral treatment failure in numerous cases. For these reasons, HIV-1-infected individuals should maintain safe sexual practices and use clean needles for injection independently of the HIV-1 serological status of their partner or the individual they are exchanging needles with. Moreover, it will be crucial to further evaluate the incidence and consequences of HIV-1 superinfection in HIV-1 controllers, and assess if the lack of clinical manifestations prior to, or after, HIV-1 superinfection is associated with an attenuated replicative capacity of the initial or superinfecting virus, respectively.

\section{Implications for HIV-1 Vaccine Design: Lessons from Other Viral Superinfections?}

Vaccination is based on the principle that exposure to specific viral antigens leads to the development of an adaptive immune response which protects the host against subsequent infections by viruses that share a sufficient number of relevant epitopes with the viral strains used to generate the vaccine, i.e. viruses that are genetically identical or close. The same principle applies to a significant number of natural viral infections and provides life-long protective immunity in hosts that have been infected once

One major challenge to develop an effective HIV-1 vaccine is to identify the correlates of protection in HIV-1 infection. One way to gain insight into that crucial question is to compare immune responses generated in the context of effective or suboptimal vaccines. Another way is to understand how a single infection with some viruses leads to development of a long-lived sterilizing immunity, while other viruses can superinfect their host, sometimes in spite of a potent immune response that allowed clearing the initial infection. Indeed, a onetime exposure to various viruses besides HIV-1 seem to confer no or only partial protection, allowing a secondary infection to occur in the presence of another viral strain against which an adaptive immune response has been mounted. Members of the herpes virus family, such as herpes simplex virus 1 [78] or 2 [79], Epstein-Barr virus [80], varicella zoster virus (reviewed in [81]), human herpes virus 8 [82], and notably cytomegalovirus (CMV) [83-88], provide remarkable examples of secondary infections in previously chronically infected hosts. For the scope of this review, we will limit the discussion to a few viruses that have a major impact on global health. 


\section{Cytomegalovirus superinfection}

CMV is a large double-stranded DNA virus belonging to the $\beta$-herpes virus family and highly prevalent in humans, with 50 $90 \%$ of individuals in the United States being seropositive, and up to $100 \%$ of individuals in developing countries. While infection remains asymptomatic in most immune competent individuals, reactivation of latent CMV infection in immunocompromised individuals can cause severe disease, and intrauterine CMV infection has serious consequences on the development of the fetus (reviewed in [89]). The production of a prophylactic vaccine for CMV has been hampered by the ability of the virus to repeatedly establish a chronic infection $[90,91]$ in the presence of high titers neutralizing antibodies and up to $10 \%$ of circulating $\mathrm{T}$ cells being CMV-specific [92]. While CMV is subdivided into several genotypes, extensive genetic diversity might not entirely explain the lack of protection by CMV-specific CD8+ T cells from the superinfecting strain, as the large size of the viral genome might allow for the generation of a significant degree of cross-reactive responses. Accordingly, based on observations made in CMV-infected Rhesus macaques, it has been proposed that productive superinfection by CMV relies on the US2, US3, US6 and US11 viral proteins that all dampen HLA class-I presentation and allow the virus to evade CMVspecific CD8+ T cell responses, while these factors are not required to establish the primary infection [93]. Thus, it cannot be ruled out that, in addition to the considerable genetic variability of HIV-1, accessory proteins such as Nef and Vpu, which have been shown to affect HLA class-I antigen presentation, contribute to counteracting existing HIV1-specific immune responses to facilitate HIV-1 superinfection.

\section{Hepatitis C and B virus superinfections}

Besides herpes viruses, hepatitis C virus (HCV) [94-100] and hepatitis B virus (HBV) [101], which can be completely cleared or persist in their host, can both superinfect chronically infected individuals, although to a different extent.

$\mathrm{HBV}$ is a partially double stranded DNA virus of the Hepadnaviridae family that chronically infects more than 240 million individuals worldwide and is a leading cause of liver insufficiency and hepatocellular carcinoma [102]. However, the majority of de novo HBV infections are cleared during the acute phase, and in contrast to most of the abovementioned viruses, a vaccine that has proven to be $95 \%$ effective can prevent $\mathrm{HBV}$ infection. In accordance with protection mediated by preexposure to the viral antigens, there is only one convincing report of HBV superinfection to date [101]. In these two patients with chronic HBV infection, superinfection with either homo- or heterotypic HBV strains led to a transient acute exacerbation of the disease, yet in both cases replication of the superinfecting virus could be suppressed by the immune system.

$\mathrm{HCV}$ is an enveloped single-stranded RNA virus of the Flaviviridae family with high genetic diversity and for which there is currently no vaccine (reviewed in [103]),[104]. While progression to chronic disease occurs in the majority of infected individuals, about one-fourth of de novo HCV infections are cleared during the acute phase. Viral clearance is thought to rely largely on a broad, potent and prolonged host cellular immune response [105-107]. Accordingly, defective T cell immunity is strongly associated with viral persistence [108]. Because their detection is currently technically challenging, there are limited reports of true HCV superinfections in the literature, yet reinfections following spontaneous clearance or treatment have been frequently documented [94-100].
Altogether, available data suggest that control of HCV infection does not confer sterilizing immunity against HCV reinfection. However, it has been suggested that previous HCV infections might confer some level of protection, as subjects with resolved HCV infection were less frequently reinfected than completely naïve individuals were infected for the first time, even in populations with a particularly high risk of exposure such as IDUs $[109,110]$. In accordance with these findings, a recent study suggested that HCV-specific immune responses in individuals who experienced spontaneous $(2 / 2)$ or treatment-mediated (2/5) HCV clearance can drive resolution of HCV reinfection [99]. Similarly, increased rates of HCV clearance were observed upon reinfection in individuals who spontaneously controlled a previous HCV infection [111]. Following a second exposure to HCV, subjects with resolved HCV infection experienced a moderate viremia in terms of persistence and amplitude, as well as increased breadth of HCVspecific $\mathrm{T}$ cell responses and emergence of cross-reactive NAbs.

To date, the frequency and the clinical consequences of HCV superinfection are poorly defined, and complicated by the fact that $\mathrm{HCV}$ replicates in the liver. Therefore, analysis of viruses present in the peripheral blood might not accurately represent the properties of hepatic viruses. It will be important to further develop techniques and cohorts to address these questions and dissect immune responses in those individuals that are able to spontaneously clear HCV infection in multiple instances. Overall, data accumulated thus far strongly suggest that protective immune responses can be mounted against HCV, and that development of a vaccine providing protection from $\mathrm{HCV}$ infection or promoting HCV clearance in naïve individuals might be possible.

\section{Conclusions}

The current knowledge about HIV-1 superinfection discussed in this review probably does not reflect the true incidence and clinical consequences of HIV-1 superinfection. As a result, it appears that immune responses developed against a specific HIV-1 strain do not necessarily provide protection against a second infection with a genetically distinct HIV-1 strain, while a significant amount of unsuccessful or controlled HIV-1 superinfections might remain undetected. Identifying these concealed situations and dissecting associated viral and immunological factors will be crucial to better understanding the immunologic correlates of protection.

The extensive genetic variability of HIV-1 remains a major challenge in the development of a protective HIV-1 vaccine. Among unsolved issues, it remains unclear to what extent epitopes are conserved across HIV-1 subtypes, and what immunogens should be included in future vaccine compositions to elicit cross-clade responses. However, the observed increase in the breath of CD8+ T cell and NAbs responses in highly exposed singly infected individuals suggests that crossreactive HIV-1-specific immune responses might be achieved by serial exposures to polyvalent HIV-1 vaccines. Another way to circumvent the circulation and ongoing generation of multiple divergent HIV-1 strains within and between individuals would be to target well-conserved viral proteins (such as regulatory or accessory proteins).

Finally, vaccine trials remain the standard for the identification of markers of protective immunity, as HIV-1 superinfection does not truly recapitulate the consequences of vaccination on the immune system, notably in relation to immune activation and exhaustion.

\section{Acknowledgement}

I would like to thank Christian Koerner and Christine Palmer for thoughtful and critical review of this manuscript, as well as the Terry and Susan Ragon Foundation for financial support. 


\section{References}

1. UNAIDS (2012) Global Report. UNAIDS Report on the Global AIDS Epidemic.

2. Walker BD, Burton DR (2008) Toward an AIDS vaccine. Science 320: 760-764.

3. NIAID (2013) NIH Discontinues Immunizations in HIV Vaccine Study.

4. Rerks-Ngarm S, Pitisuttithum P, Nitayaphan $S$, Kaewkungwal J, Chiu J, et al. (2009) Vaccination with ALVAC and AIDSVAX to prevent HIV-1 infection in Thailand. N Engl J Med 361: 2209-2220.

5. Chohan BH, Piantadosi A, Overbaugh J (2010) HIV-1 superinfection and its implications for vaccine design. Curr HIV Res 8: 596-601.

6. HIV Sequence Database Web Site: Theoretical biology and biophysics group, Los Alamos National Laboratory.

7. Ndung'u T, Weiss RA (2012) On HIV diversity. AIDS 26: 1255-1260.

8. Monajemi M, Woodworth CF, Benkaroun J, Grant M, Larijani M (2012) Emerging complexities of APOBEC3G action on immunity and viral fitness during HIV infection and treatment. Retrovirology 9: 35.

9. Altfeld M, Allen TM, Yu XG, Johnston MN, Agrawal D, et al. (2002) HIV-1 superinfection despite broad $\mathrm{CD} 8+\mathrm{T}$-cell responses containing replication of the primary virus. Nature $420: 434-439$.

10. Jost S, Bernard MC, Kaiser L, Yerly S, Hirschel B, et al. (2002) A patient with HIV-1 superinfection. $N$ Engl J Med 347: 731-736.

11. Ramos A, Hu DJ, Nguyen L, Phan KO, Vanichseni S, et al. (2002) Intersubtype human immunodeficiency virus type 1 superinfection following seroconversion to primary infection in two injection drug users. J Virol 76: 7444-7452.

12. Allen TM, Altfeld M (2003) HIV-1 superinfection. J Allergy Clin Immunol 112: 829-835.

13. Benson RE, Sanfridson A, Ottinger JS, Doyle C, Cullen BR (1993) Downregulation of cell-surface CD4 expression by simian immunodeficiency virus Nef prevents viral super infection. J Exp Med 177: 1561-1566.

14. Volsky DJ, Simm M, Shahabuddin M, Li G, Chao W, et al. (1996) Interference to human immunodeficiency virus type 1 infection in the absence of downmodulation of the principal virus receptor, CD4. J Virol 70: 3823-3833.

15. Taddeo B, Federico M, Titti F, Rossi GB, Verani P (1993) Homologous superinfection of both producer and nonproducer HIV-infected cells is blocked at a late retrotranscription step. Virology 194: 441-452.

16. Fultz PN, Srinivasan A, Greene CR, Butler D, Swenson RB, et al. (1987) Superinfection of a chimpanzee with a second strain of human immunodeficiency virus. J Virol 61: 4026-4029.

17. Li Y, Liu Q, Luo Z, Feng Y, Li Z, et al. (2012) Partial protection of SHIV-infected Chinese rhesus macaques against super-infection with heterologous SHIV isolate. Curr HIV Res 10: 627-635.

18. Wakrim L, Le Grand R, Vaslin B, ChéretA, Matheux F, et al. (1996) Superinfection of HIV-2-preinfected macaques after rectal exposure to a primary isolate of SIVmac251. Virology 221: 260-270.

19. Yeh WW, Jaru-Ampornpan P, Nevidomskyte D, Asmal M, Rao SS, et al. (2009) Partial protection of Simian immunodeficiency virus (SIV)-infected rhesus monkeys against superinfection with a heterologous SIV isolate. J Virol 83: 2686-2696.

20. Wei Q, Fultz PN (1998) Extensive diversification of human immunodeficiency virus type 1 subtype $B$ strains during dual infection of a chimpanzee that progressed to AIDS. J Virol 72: 3005-3017.

21. Novembre FJ, de Rosayro J, Nidtha S, O'Neil SP, Gibson TR, et al. (2001) Rapid CD4(+) T-cell loss induced by human immunodeficiency virus type 1 (NC) in uninfected and previously infected chimpanzees. J Virol 75: 1533-1539.

22. Otten RA, Ellenberger DL, Adams DR, Fridlund CA, Jackson E, et al. (1999) Identification of a window period for susceptibility to dual infection with two distinct human immunodeficiency virus type 2 isolates in a Macaca nemestrina (pig-tailed macaque) model. J Infect Dis 180: 673-684.

23. Chohan B, Lavreys L, Rainwater SM, Overbaugh J (2005) Evidence for frequent reinfection with human immunodeficiency virus type 1 of a different subtype. J Virol 79: 10701-10708.

24. Gottlieb GS, Nickle DC, Jensen MA, Wong KG, Kaslow RA, et al. (2007) HIV type 1 superinfection with a dual-tropic virus and rapid progression to AIDS: a case report. Clin Infect Dis 45: 501-509.
25. Hu DJ, Subbarao S, Vanichseni S, Mock PA, Ramos A, et al. (2005) Frequency of HIV-1 dual subtype infections, including intersubtype superinfections, among injection drug users in Bangkok, Thailand. AIDS 19: 303-308.

26. Manigart O, Courgnaud V, Sanou O, Valéa D, Nagot N, et al. (2004) HIV-1 superinfections in a cohort of commercial sex workers in Burkina Faso as assessed by an autologous heteroduplex mobility procedure. AIDS 18: 16451651.

27. McCutchan FE, Hoelscher M, Tovanabutra S, Piyasirisilp S, SandersBuell E, et al. (2005) In-depth analysis of a heterosexually acquired human immunodeficiency virus type 1 superinfection: evolution, temporal fluctuation, and intercompartment dynamics from the seronegative window period through 30 months postinfection. J Virol 79: 11693-11704.

28. van der Kuyl AC, Kozaczynska K, van den Burg R, Zorgdrager F, Back N, et al. (2005) Triple HIV-1 infection. N Engl J Med 352: 2557-2559.

29. Yerly S, Jost S, Monnat M, Telenti A, Cavassini M, et al. (2004) HIV-1 co/superinfection in intravenous drug users. AIDS 18: 1413-1421.

30. Gottlieb GS, Nickle DC, Jensen MA, Wong KG, Grobler J, et al. (2004) Dual HIV-1 infection associated with rapid disease progression. Lancet 363: 619622.

31. Koelsch KK, Smith DM, Little SJ, Ignacio CC, Macaranas TR, et al. (2003) Clade B HIV-1 superinfection with wild-type virus after primary infection with drug-resistant clade B virus. AIDS 17: F11-16.

32. Pernas M, Casado C, Fuentes R, Pérez-Elías MJ, López-Galíndez C (2006) A dual superinfection and recombination within HIV-1 subtype B 12 years after primoinfection. J Acquir Immune Defic Syndr 42: 12-18.

33. Smith DM, Wong JK, Hightower GK, Ignacio CC, Koelsch KK, et al. (2004) Incidence of HIV superinfection following primary infection. JAMA 292: 11771178.

34. Yang OO, Daar ES, Jamieson BD, Balamurugan A, Smith DM, et al. (2005) Human immunodeficiency virus type 1 clade $B$ superinfection: evidence for differential immune containment of distinct clade B strains. J Virol 79: 860-868.

35. Streeck H, Li B, Poon AF, Schneidewind A, Gladden AD, et al. (2008) Immunedriven recombination and loss of control after HIV superinfection. J Exp Med 205: 1789-1796

36. Kozaczynska K, Cornelissen M, Reiss P, Zorgdrager F, van der Kuyl AC (2007) HIV-1 sequence evolution in vivo after superinfection with three viral strains. Retrovirology 4: 59.

37. Plantier JC, Lemée V, Dorval I, Gueudin M, Braun J, et al. (2004) HIV-1 group $M$ superinfection in an HIV-1 group O-infected patient. AIDS 18: 2444-2446.

38. Günthard HF, Huber M, Kuster H, Shah C, Schüpbach J, et al. (2009) HIV-1 superinfection in an HIV-2-infected woman with subsequent control of HIV-1 plasma viremia. Clin Infect Dis 48: e117-120.

39. Promadej-Lanier N, Thielen C, Hu DJ, Chaowanachan T, Gvetadze R, et al (2009) Cross-reactive T cell responses in HIV CRF01_AE and B'-infected intravenous drug users: implications for superinfection and vaccines. AIDS Res Hum Retroviruses 25: 73-81.

40. Blish CA, Dogan OC, Jaoko W, McClelland RS, Mandaliya K, et al. (2012) Cellular immune responses and susceptibility to HIV-1 superinfection: a casecontrol study. AIDS 26: 643-646.

41. Willberg CB, McConnell JJ, Eriksson EM, Bragg LA, York VA, et al. (2008) Immunity to HIV-1 is influenced by continued natural exposure to exogenous virus. PLoS Pathog 4: e1000185.

42. Smith DM, Strain MC, Frost SD, Pillai SK, Wong JK, et al. (2006) Lack of neutralizing antibody response to HIV-1 predisposes to superinfection. Virology 355: $1-5$

43. Basu D, Kraft CS, Murphy MK, Campbell PJ, Yu T, et al. (2012) HIV-1 subtype C superinfected individuals mount low autologous neutralizing antibody responses prior to intrasubtype superinfection. Retrovirology 9: 76 .

44. Blish CA, Dogan OC, Derby NR, Nguyen MA, Chohan B, et al. (2008) Human immunodeficiency virus type 1 superinfection occurs despite relatively robust neutralizing antibody responses. J Virol 82: 12094-12103.

45. Mikell I, Sather DN, Kalams SA, Altfeld M, Alter G, et al. (2011) Characteristics of the earliest cross-neutralizing antibody response to HIV-1. PLoS Pathog 7: e1001251. 
46. Cortez V, Odem-Davis K, McClelland RS, Jaoko W, Overbaugh J (2012) HIV-1 superinfection in women broadens and strengthens the neutralizing antibody response. PLoS Pathog 8: e1002611.

47. Powell RL, Kinge T, Nyambi PN (2010) Infection by discordant strains of HIV-1 markedly enhances the neutralizing antibody response against heterologous virus. J Virol 84: 9415-9426.

48. Mayr LM, Powell RL, Ngai JN, Takang WA, Nádas A, et al. (2012) Superinfection by discordant subtypes of HIV-1 does not enhance the neutralizing antibody response against autologous virus. PLoS One 7: e38989.

49. Ackerman ME, Dugast AS, Alter G (2012) Emerging concepts on the role of innate immunity in the prevention and control of HIV infection. Annu Rev Med 63: $113-130$.

50. Forthal DN, Landucci G, Chohan B, Richardson BA, McClelland RS, et al. (2013) Antibody-dependent cell-mediated virus inhibition antibody activity does not correlate with risk of HIV-1 superinfection. J Acquir Immune Defic Syndr 63: 31-33.

51. Rachinger A, Manyenga P, Burger JA, Derks van de Ven TL, Stolte IG, et al. (2011) Low incidence of HIV-1 superinfection even after episodes of unsafe sexual behavior of homosexual men in the Amsterdam Cohort Studies on HIV Infection and AIDS. J Infect Dis 203: 1621-1628.

52. Templeton AR, Kramer MG, Jarvis J, Kowalski J, Gange S, et al. (2009) Multiple-infection and recombination in HIV-1 within a longitudinal cohort of women. Retrovirology 6: 54

53. Waters L, Smit E (2012) HIV-1 superinfection. Curr Opin Infect Dis 25: 42-50.

54. Piantadosi A, Chohan B, Chohan V, McClelland RS, Overbaugh J (2007) Chronic HIV-1 infection frequently fails to protect against superinfection. PLoS Pathog 3: e177.

55. Redd AD, Mullis CE, Serwadda D, Kong X, Martens C, et al. (2012) The rates of HIV superinfection and primary HIV incidence in a general population in Rakai, Uganda. J Infect Dis 206: 267-274.

56. Diaz RS, Pardini R, Catroxo M, Operskalski EA, Mosley JW, et al. (2005) HIV-1 superinfection is not a common event. J Clin Virol 33: 328-330.

57. Gonzales MJ, Delwart E, Rhee SY, Tsui R, Zolopa AR, et al. (2003) Lack of detectable human immunodeficiency virus type 1 superinfection during 1072 person-years of observation. J Infect Dis 188: 397-405.

58. Rachinger A, Stolte IG, van de Ven TD, Burger JA, Prins M, et al. (2010) Absence of HIV-1 superinfection 1 year after infection between 1985 and 1997 coincides with a reduction in sexual risk behavior in the seroincident Amsterdam cohort of homosexual men. Clin Infect Dis 50: 1309-1315.

59. Tsui R, Herring BL, Barbour JD, Grant RM, Bacchetti P, et al. (2004) Human immunodeficiency virus type 1 superinfection was not detected following 215 years of injection drug user exposure. J Virol 78: 94-103.

60. Doyle T, Garcia-Diaz AM, Ambrose J, Strang A, Cambiano V, et al. (2011) Detecting HIV-1 superinfection by pol gene population sequencing among untreated HIV-1-infected men who experience sudden rises in plasma HIV-1 RNA load. AIDS 25: 542-544.

61. Jurriaans S, Kozaczynska K, Zorgdrager F, Steingrover R, Prins JM, et al. (2008) A sudden rise in viral load is infrequently associated with HIV-1 superinfection. J Acquir Immune Defic Syndr 47: 69-73.

62. Piantadosi A, Ngayo MO, Chohan B, Overbaugh J (2008) Examination of a second region of the HIV type 1 genome reveals additional cases of superinfection. AIDS Res Hum Retroviruses 24: 1221.

63. Rachinger $A$, van de Ven TD, Burger JA, Schuitemaker $H$, van 't Wout $A B$ (2010) Evaluation of pre-screening methods for the identification of HIV-1 superinfection. J Virol Methods 165: 311-317.

64. Pacold M, Smith D, Little S, Cheng PM, Jordan P, et al. (2010) Comparison of methods to detect HIV dual infection. AIDS Res Hum Retroviruses 26: 12911298.

65. Redd AD, Collinson-Streng A, Martens C, Ricklefs S, Mullis CE, et al. (2011) Identification of HIV superinfection in seroconcordant couples in Rakai, Uganda, by use of next-generation deep sequencing. J Clin Microbiol 49: 2859-2867.

66. Brenner B, Routy JP, Quan Y, Moisi D, Oliveira M, et al. (2004) Persistence of multidrug-resistant HIV-1 in primary infection leading to superinfection. AIDS 18: $1653-1660$
67. Chakraborty B, Kiser P, Rangel HR, Weber J, Mirza M, et al. (2004) Can HIV-1 superinfection compromise antiretroviral therapy? AIDS 18: 132-134.

68. van der Kuyl AC, Kozaczynska K, Ariën KK, Gali Y, Balázs VR, et al. (2010) Analysis of infectious virus clones from two HIV-1 superinfection cases suggests that the primary strains have lower fitness. Retrovirology 7: 60

69. Chakraborty B, Valer L, De Mendoza C, Soriano V, Quiñones-Mateu ME (2004) Failure to detect human immunodeficiency virus type 1 superinfection in 28 HIV-seroconcordant individuals with high risk of reexposure to the virus. AIDS Res Hum Retroviruses 20: 1026-1031.

70. Blick G, Kagan RM, Coakley E, Petropoulos C, Maroldo L, et al. (2007) The probable source of both the primary multidrug-resistant (MDR) HIV-1 strain found in a patient with rapid progression to AIDS and a second recombinant MDR strain found in a chronically HIV-1-infected patient. J Infect Dis 195: 1250 1259.

71. Smith DM, Wong JK, Hightower GK, Ignacio CC, Koelsch KK, et al. (2005) HIV drug resistance acquired through superinfection. AIDS 19: 1251-1256.

72. Thèze J, Chakrabarti LA, Vingert B, Porichis F, Kaufmann DE (2011) HIV controllers: a multifactorial phenotype of spontaneous viral suppression. Clin Immunol 141: 15-30.

73. Clerc O, Colombo S, Yerly S, Telenti A, Cavassini M (2010) HIV-1 elite controllers: beware of super-infections. J Clin Virol 47: 376-378.

74. Fang G, Weiser B, Kuiken C, Philpott SM, Rowland-Jones S, et al. (2004) Recombination following superinfection by HIV-1. AIDS 18: 153-159.

75. Casado C, Pernas M, Alvaro T, Sandonis V, García S, et al. (2007) Coinfection and superinfection in patients with long-term, nonprogressive HIV-1 disease. J Infect Dis 196: 895-899.

76. Lamine A, Caumont-Sarcos A, Chaix ML, Saez-Cirion A, Rouzioux C, et al. (2007) Replication-competent HIV strains infect HIV controllers despite undetectable viremia (ANRS EP36 study). AIDS 21: 1043-1045.

77. Weinfurter JT, May GE, Soma T, Hessell AJ, León EJ, et al. (2011) Macaque long-term nonprogressors resist superinfection with multiple CD8+ $\mathrm{T}$ cell escape variants of simian immunodeficiency virus. J Virol 85: 530-541.

78. Roest RW, Carman WF, Maertzdorf J, Scoular A, Harvey J, et al. (2004) Genotypic analysis of sequential genital herpes simplex virus type 1 (HSV-1) isolates of patients with recurrent HSV-1 associated genital herpes. J Med Viro 73: 601-604.

79. Roest RW, Maertzdorf J, Kant M, van der Meijden WI, Osterhaus AD, et al (2006) High incidence of genotypic variance between sequential herpes simplex virus type 2 isolates from HIV-1-seropositive patients with recurren genital herpes. J Infect Dis 194: 1115-1118.

80. van Baarle D, Hovenkamp E, Kersten MJ, Klein MR, Miedema F, et al. (1999) Direct Epstein-Barr virus (EBV) typing on peripheral blood mononuclear cells: no association between EBV type 2 infection or superinfection and the development of acquired immunodeficiency syndrome-related non-Hodgkin's lymphoma. Blood 93: 3949-3955.

81. Quinlivan M, Breuer J (2006) Molecular studies of Varicella zoster virus. Rev Med Virol 16: 225-250.

82. Beyari MM, Hodgson TA, Cook RD, Kondowe W, Molyneux EM, et al. (2003) Multiple human herpesvirus-8 infection. J Infect Dis 188: 678-689.

83. Gorman S, Harvey NL, Moro D, Lloyd ML, Voigt V, et al. (2006) Mixed infection with multiple strains of murine cytomegalovirus occurs following simultaneous or sequential infection of immunocompetent mice. J Gen Virol 87: 1123-1132.

84. Boppana SB, Rivera LB, Fowler KB, Mach M, Britt WJ (2001) Intrauterine transmission of cytomegalovirus to infants of women with preconceptional immunity. N Engl J Med 344: 1366-1371.

85. Bale JF Jr, Petheram SJ, Souza IE, Murph JR (1996) Cytomegalovirus reinfection in young children. J Pediatr 128: 347-352.

86. Spector SA, Hirata KK, Newman TR (1984) Identification of multiple cytomegalovirus strains in homosexual men with acquired immunodeficiency syndrome. J Infect Dis 150: 953-956.

87. Drew WL, Sweet ES, Miner RC, Mocarski ES (1984) Multiple infections by cytomegalovirus in patients with acquired immunodeficiency syndrome: documentation by Southern blot hybridization. J Infect Dis 150: 952-953.

88. Meyer-König U, Ebert K, Schrage B, Pollak S, Hufert FT (1998) Simultaneous 
infection of healthy people with multiple human cytomegalovirus strains. Lancet 352: $1280-1281$.

89. Kenneson A, Cannon MJ (2007) Review and meta-analysis of the epidemiology of congenital cytomegalovirus (CMV) infection. Rev Med Virol 17: 253-276.

90. Plotkin SA, Starr SE, Friedman HM, Gönczöl E, Weibel RE (1989) Protective effects of Towne cytomegalovirus vaccine against low-passage cytomegalovirus administered as a challenge. J Infect Dis 159: 860-865

91. Adler SP, Starr SE, Plotkin SA, Hempfling SH, Buis J, et al. (1995) Immunity induced by primary human cytomegalovirus infection protects against secondary infection among women of childbearing age. J Infect Dis 171: 26-32.

92. Sylwester AW, Mitchell BL, Edgar JB, Taormina C, Pelte C, et al. (2005) Broadly targeted human cytomegalovirus-specific CD4+ and CD8+ T cells dominate the memory compartments of exposed subjects. J Exp Med 202: 673-685.

93. Hansen SG, Powers CJ, Richards R, Ventura AB, Ford JC, et al. (2010) Evasion of CD8+ $T$ cells is critical for superinfection by cytomegalovirus. Science 328 : 102-106.

94. Blackard JT, Sherman KE (2007) Hepatitis C virus coinfection and superinfection. J Infect Dis 195: 519-524.

95. Bate JP, Colman AJ, Frost PJ, Shaw DR, Harley HA (2010) High prevalence of late relapse and reinfection in prisoners treated for chronic hepatitis C. J Gastroenterol Hepatol 25: 1276-1280.

96. Grebely J, Knight E, Ngai T, Genoway KA, Raffa JD, et al. (2010) Reinfection with hepatitis $C$ virus following sustained virological response in injection drug users. J Gastroenterol Hepatol 25: 1281-1284.

97. Currie SL, Ryan JC, Tracy D, Wright TL, George S, et al. (2008) A prospective study to examine persistent $\mathrm{HCV}$ reinfection in injection drug users who have previously cleared the virus. Drug Alcohol Depend 93: 148-154.

98. Dalgard O (2005) Follow-up studies of treatment for hepatitis $C$ virus infection among injection drug users. Clin Infect Dis 40 Suppl 5: S336-338.

99. Grebely J, Pham ST, Matthews GV, Petoumenos K, Bull RA, et al. (2012) Hepatitis $C$ virus reinfection and superinfection among treated and untreated participants with recent infection. Hepatology 55: 1058-1069.
100.Pham ST, Bull RA, Bennett JM, Rawlinson WD, Dore GJ, et al. (2010) Frequent multiple hepatitis $C$ virus infections among injection drug users in a prison setting. Hepatology 52: 1564-1572.

101. Kao JH, Chen PJ, Lai MY, Chen DS (2001) Acute exacerbations of chronic hepatitis B are rarely associated with superinfection of hepatitis B virus. Hepatology 34: 817-823.

102. WHO World Health Organization (2012) Hepatitis B. World Health Organization Fact Sheet 204

103. Lavanchy D (2009) The global burden of hepatitis C. Liver Int 29 Suppl 1: 74-81.

104. Choo QL, Kuo G, Weiner AJ, Overby LR, Bradley DW, et al. (1989) Isolation of a cDNA clone derived from a blood-borne non-A, non-B viral hepatitis genome. Science 244: 359-362.

105.Lauer GM, Ouchi K, Chung RT, Nguyen TN, Day CL, et al. (2002) Comprehensive analysis of CD8(+)-T-cell responses against hepatitis $\mathrm{C}$ virus reveals multiple unpredicted specificities. J Virol 76: 6104-6113.

106. Grakoui A, Shoukry NH, Woollard DJ, Han JH, Hanson HL, et al. (2003) $\mathrm{HCV}$ persistence and immune evasion in the absence of memory $\mathrm{T}$ cell help. Science 302: 659-662.

107. Day CL, Lauer GM, Robbins GK, McGovern B, Wurcel AG, et al. (2002) Broad specificity of virus-specific CD4+ T-helper-cell responses in resolved hepatitis C virus infection. J Virol 76: 12584-12595.

108. Ulsenheimer A, Gerlach JT, Gruener NH, Jung MC, Schirren CA, et al. (2003) Detection of functionally altered hepatitis $\mathrm{C}$ virus-specific CD4 T cells in acute and chronic hepatitis C. Hepatology 37: 1189-1198.

109. Grebely J, Conway B, Raffa JD, Lai C, Krajden M, et al. (2006) Hepatitis C virus reinfection in injection drug users. Hepatology 44: 1139-1145.

110. Mehta SH, Cox A, Hoover DR, Wang XH, Mao Q, et al. (2002) Protection against persistence of hepatitis $C$. Lancet 359: 1478-1483

111. Osburn WO, Fisher BE, Dowd KA, Urban G, Liu L, et al. (2010) Spontaneous control of primary hepatitis $C$ virus infection and immunity against persistent reinfection. Gastroenterology 138: 315-324. 